\title{
Penerapan Media Dinding dalam Meningkatkan Service Forehand Backhand pada Pembelajaran Tenis Meja
}

\author{
Yarmani \\ Penjas fkip unib, e-mail: yarmani62penjas@gmail.com
}

\section{Tono sugihartono}

Universitas Bengkulu

Defliyanto

Universitas Bengkulu

\begin{abstract}
ABSTRAK
Penelitian ini bertujuan untuk mengetahui peningkatan proses belajar mengajar tenis meja pada servis forehand dan backhand melalui media dinding pada mahasiswa penjas. Penelitian dilakukan pada jam belajar mata kuliah pilihan semester tiga mahasiswa penjas. Metode penelitian yang digunakan adalah penelitian tindakan kelas (PTK), penelitian ini secara obyektif atau apa adanya dengan subyek mahasiswa penjas mata kuliah pilihan tenis meja berjumlah 30 orang. Penelitian ini dilakukan dalam 2 siklus, setiap siklus terdiri dari 3 tahap yaitu : (1) pendahuluan, (2) Inti (3) Penutup . Jenis data yang dikumpulkan proses belajar - mengajar berlangsung. Adapun hasil pengamatan terhadap mahasiswa dalam proses belajar mengajar pada servis forehand dan backhand melalui media dinding permainan tenis meja pada siklus I adalah sebesar $55 \%$ dari keseluruhan pengamatan terhadap proses belajar mengajar. Pada siklus II meningkat menjadi 85\%. Sedangkan hasil pengamatan terhadap dosen pada siklus I sebesar $65 \%$ dan meningkat pada siklus II menjadi $90 \%$. Sehingga dapat disimpulkan bahwa adanya peningkatan yang sangat berarti dalam penerapan pembelajaran servis forehand dan backhand melalui media dinding pada mahasiswa penjas.
\end{abstract}

Kata Kunci : Penerapan Media Dinding, Service Forehand Backhand, Tenis Meja.

\begin{abstract}
This study aims to determine the improvement in the learning process of table tennis on forehand and backhand service through the wall media for Physical Education students. The study was conducted on the hours of learning elective courses of the third semester Physical Education students. The research method used was classroom action research (CAR), this study objectively or as it is with the subject physical education students in elective courses table tennis, amounting to 30 people. This research was conducted in 2 cycles, each cycle consisting of 3 stages: (1) introduction, (2) Core (3) Closing. The type of data collected in the teaching and learning process. As for the results of observations of students in the teaching
\end{abstract}


and learning process in the forehand and backhand service through the table tennis wall media in the first cycle were $55 \%$ of all observations of the teaching and learning process. In the second cycle increased to $85 \%$. While the observations of lecturers in the first cycle were $65 \%$ and increased in the second cycle to $90 \%$. So it can be concluded that there was a very significant increase in the application of learning forehand and backhand services through wall media on Physical Education students.

Keywords: Application of Wall Media, Forehand Backhand Service, Table Tennis.

\section{PENDAHULUAN}

Mata Kuliah Pembelajaran Tenis meja merupakan salah satu mata kuliah pilihan pada program studi Pendidikan Jasmani dimana mahasiswa yang memilih mata kuliah tersebut akan melalui proses pembelajaran dalam tenis meja dalam satu semester. Mahasiswa dituntut agar bisa menguasai teknik dasar pukulan dalam tenis meja. Salah satu materi pokok yang harus dikuasai dengan standar minimal penguasan keterampilan Tenis meja baik adalah materi Tenis meja, yang secara spesifik gerakannya di lihat dari pukulan service berdasarkan hasil perkuliahan tahun 2016-2017 belum mencapai target yang diharapkan, mahasiswa mendapat nilai baik sekali sebesar $10 \%$, nilai baik sebesar $20 \%$, nilai cukup sebesar $30 \%$ dan nilai kurang $40 \%$., Hasil tersebut tentu saja belum memenuhi baik standar kelulusan kelas, maupun standar minimal individual.

Beberapa hal yang menjadi kendala pembelajaran Tenis meja pada mahasiswa Penjaskes, berdasarkan hasil penelitian pendahuluan terungkap bahwa; 1) sebagian besar mahasiswa belum menguasai teknik dasar servis yang benar, 2) mahasiswa kurang cepat dalam melakukan pukulan servis 3) pukulan mahasiswa masih kurang tepat akibat masalah di atas, minat dan motivasi belajar pada pembelajaran Tenis meja menjadi rendah, mahasiswa cenderung sekedar mengikuti perkuliahan saja tapi tidak benar-benar serius dalam penguasaan teknik dasar pukulan. Hal ini mungkin di disebabkan karena tidak adanya media dalam pembelajaran tersebut maka dosen perlu menerapkan media pembelajaran dalam permainan tenis meja dalam meningkatkan hasilbelajar.

Sementara itu permasalahan juga muncul karena 1) perlengkapan dan alat penunjang praktek kurang mendukung kebutuhan mahasiswa untuk melakukan latihan-latihan dengan frekuensi yang cukup, hal itu karena terbatasnya alat yang tersedia dengan jumlah mahasiswa yang cukup banyak 10 - 15 orang/kelas; 2) Ruang Tenis meja di kampus air sebakul terlalu sempit untuk menampung sejumlah mahasiswa, sehingga area pergerakan mahasiswa berlatih sangat terbatas; 3). Tidak adanya media pembelajaran sehingga mahasiswa merasa jenuh dan monoton.

Beberapa situasi dan kondisi sebagai kendala atau hambatan proses pembelajaran Tenis meja yang telah dikemukakan di atas, perlu adanya langkahlangkah dalam rangka mengeksplorasi proses pembelajaran agar lebih efektif dan efisien serta hasil pembelajaran juga meningkat. Dalam hal lain setelah mahasiswa menyelesaikan masa studinya, diharapkan mahasiswa mampu menyajikan pembelajaran pada mahasiswanya secara baik dengan strategi yang tepat, mampu membelajarkan mahasiswa dengan aktif, inovatif, kreatif, efisien dan menyenangkan (Paikem). Salah satu langkah agar terjadi 
pembelajaran yang paikem, guru hendaknya beralih pandangan dari mengajar sebagai sumber otoritas menuju pada perannya sebagai fasilitator dan mediator yang kreatif, sehingga dapat mengembangkan kemampuan berpikir mahasiswa (Widi,2007:2).

Menurut pandangan Mosston \& Asworth, 1994 dalam (Irwandi (2009:55) bahwa guru harus selalu menempuh pendekatan baru, dengan menerapkan serta memanfaatkan bermacam-macam keterampilan mengajar, metode dan gaya mengajar yang dapat berinteraksi secara efektif dengan lingkungan belajar yang khusus, unik dan khas. pembelajaran ini dapat meningkatkan kemampuan mahasiswa dalam proses pembelajaran.

Berdasarkan latarbelakang masalah yang dikemukakan, maka diharapkan penerapan melalui media dinding dalam materi Tenis meja dapat menciptakan pembelajaran Tenis meja yang aktif dan kreatif merangsang mahasiswa untuk meningkatkan hasil belajar tenis meja menjadi lebih baik dalam memecahkan permasalahan yang dirasakannya, sehingga keterampilan tenis meja dengan sendiri dapat meningkat lebih baik.

\section{METODE}

Penelitian ini menggunakan penelitian terapan (Applied Research), salah satu penelitian ini menggunakan pendekatan Penelitian Tindakan Kelas (Classroom Action Research). Penelitian Tindakan Kelas ( PTK) ini salah satu alternatif penelitian terapan untuk meningkatkan dan memperbaiki Kinerja pembelajaran di kelas atau lapangan (Carr \& Kemmis 1991, dalam IGK Wardani, 2007).

Prosedur penelitian yang digunakan dalam memecahkan permasalahan penelitian ini menggunakan rancangan Penelitian Tindakan Kelas (PTK) berkolaborasi (collaborative classroom action research).
Adapun pelaksanaannya terdiri tiga langkah yaitu: (1) Perumusan masalah, (2) Perbaikan yang terdiri atas beberapa siklus yang meliputi(a) Perencanaan(planning),(b) Pelaksanaan/tindakan(action),(c)Pengamata n (observation \& evaluation), (d) Refleksi (reflexion), dan (3) pemantapan (Beker, 2001; Elliot, 1993; dan Borgg dan Biklen, 1992 dalam Suharsimi Arikunto 2002 ). Dalam hal ini penelitian akan dilakukan sedikitnya 3 siklus, yang tiap siklusnya terdiri dari 2 kali pertemuan terhadap subjek yang diteliti. Tahap-tahap penelitian berikutnya dilakukan secara sistematis seperti langkahlangkah sebelumnya mulai dari perencanaan kembali, pelaksanaan tindakan, observasi dan refleksi.

\section{Perencanaan Tindakan (Plan)}

Perencanaan proses penelitian ditentukan secara matang bersama-sama dengan teman sejawat (1 orang dosen) dan dibantu oleh 3 orang mahasiswa tentang persiapan pembelajaran Tenis meja melalui media dinding. Perencanaan tindakan kelas ini direncanakan dalam beberapa siklus (2-3 siklus) dan setiap siklus dilakukan dua kali pertemuan. Kemudian data yang diperoleh setiap siklus akan dianalisis dan dicari pemecahan permasalahannya bersamasama dengan anggota peneliti. Hal-hal yang dipersiapkan dalam perencanaan tindakan antara lain: a) Membuat silabus pembelajaran Tenis meja.; b) Membuat skenario pembelajaran Tenis meja media dinding c) Menyiapkan lembar observasi untuk mengetahui proses pembelajaran yang dilakukan oleh dosen dan mahasiswa sebagai kondisi belajar mengajar di kelas pada saat melaksanakan tindakan; d) Menyiapkan alat tes keterampilan.

2. Pelaksanaan Tindakan. (Action)

Pada tahap ini semua yang telah direncanakan akan dilaksanakan oleh peneliti sesuai dengan rencana yang dibuat dan disepakati. Peneliti dalam hal ini bertindak sebagai pelaku pembelajaran 
melaksanakan pembelajaran sesuai dengan langkah-langkah skenario pembelajaran Tenis melalui media dinding.

3.Pengamatan/Observasi.

Tahap ini merupakan tahap pengamatan terhadap proses dan hasil pembelajaran Tenis meja pada kelas yang akan diteliti. Pada tahap ini peneliti dibantu oleh 1 orang observer yaitu teman sejawat/ dosen.

4.Refleksi.

Berdasarkan hasil observasi yang dilakukan anggota peneliti sebagai observer, temuantemuan yang diperoleh kemudian dilaksanakan kajian mendalam (refleksi) secara berkolaboratif untuk mengetahui apakah ada dampak pengiring hasil pembelajaran baik yang positif maupun yang negatif. Jika ada permasalahan baru yang muncul maka hal ini dapat dijadikan sebagai dasar untuk melaksanakan tindakan pada siklus berikutnya.

Waktu Penelitian, Penelitian dilaksanakan pada semester ganjil (semester 3 mei sampai oktober. Tempat penelitian dilaksanakan pada Program studi S-1 Penjas FKIP Universitas Bengkulu, Kampus Air Sebakul. Subjek Penelitian dalam Penelitian ini adalah dosen pengampu mata kuliah pilihan, metodik Tenis meja dan mahamahasiswa program studi S-1 Penjas semester 3 yang berjumlah 30 orang,

\section{HASIL DAN PEMBAHASAN}

\section{Hasil Penelitian}

1.Karakteristik Subjek dan objek Penelitian Subjek penelitian ini adalah 1) dosen pengampu mata kuliah tenis meja yang dalam hal ini adalah bertindak sebagai peneliti, dan 2) yang diberikan perlakuan adalah mahasiswa semester 3 tahun ajaran 2018 yang berjumlah 30 orang (25 orang laki-laki dan 5 orang perempuan). Mata kuliah tenis meja merupakan matakuliah pilihan yang ada pada semester ganjil yang sub bagiannya adalah servis forehand dan backhand melalui media dinding sehingga materi ini wajib dikuasai oleh mahasiswa Penjas. Mahasiswa yang mengambil matakuliah ini, seluruhnya merupakan orang dewasa, artinya secara fisik dapat mendukung untuk mengikuti materi ini dengan baik. Berdasarkan pengalaman, mata kuliah tenis meja merupakan mata kuliah pilihan yang kurang banyak diminat karena tingkat kesulitan dalam melakukan Teknik servis. Baik itu servis forehand dan backhand karena dibutuhkan Teknik yang baik dan pengulangan yang terus menerus agar bisa melakukannya dengan sempurna. Untuk mendukung pembelajaran, kondisi alat perlengkapan pembelajaran dan fasilitas perkuliahan cukup memadai. Selain ruang yang digunakan yaitu meja tenis meja, bat, net dan bola.

2. Proses dan Temuan dalam Pra Siklus.

Pada awal kegiatan, peneliti terlebih dahulu melakukan tes awal. Tes awal ini dilakukan untuk mengetahui sejauh mana tingkat kemampuan mahasiswa dalam melakukan servis pukulan forehand dan backhand sebelum diterapkan pembelajaran dengan penerapan media dinding. Dari perolehan data awal ini dapat diketahui bahwa sebagian besar mahasiswa mengalami kesulitan melakukan gerakan servis.

Hasil belajar pukulan servis Mahasiswa laki-laki lebih baik dibandingkan dengan mahasiswa perempuan. 25 mahasiswa laki-laki hanya 5 orang atau hanya $15 \%$ saja yang berhasil menguasai dan terampil dalam Teknik servis forehand dan backhand, sedangkan $85 \%$ lainnya mahasiswa belum menguasai dan belum terampil, tetapi secara keseluruhan dalam kelas tersebut, sebagai berikut: 
1) $85 \%$ mahasiswa tidak dapat melakukan servis forehand dan backhand dengan sempurna.

2) Teknik gerakan memegang bat masih banyak yang salah dan Gerakan serta posisi badan masih kaku artinya melakukannya kurang lincah.

3) Melakukan pukulan servis forehand dan backhand kurang akurat dan kurang cermat.

4) Belum adanya media untuk mempermudah mahasiswa dalam melakukan servis.

Dari temuan awal tersebut, disimpulkan bahwa kesulitan-kesulitan mahasiswa dalam melakukan servis forehand dan backhand disebabkan oleh 4 faktor di atas.

3. Pelaksanaan Tindakan perbaikan pembelajaran.

Siklus Pertama.

1) Perencanaan.

(a) Temuan-temuan pada pra-siklus dijadikan sebagai landasan peneliti untuk merencanakan langkah-langkah penelitian. Langkah pertama ditempuh peneliti bersama-sama dengan rekan sejawat dosen sebelum tindakan dilaksanakan antara lain mengindentifikasi data-data hasil tes keterampilan mahasiswa yang diperoleh dari tes awal keterampilan maupun hasil observasi faktor-faktior penilaian rangkaian servis forehand dan backhand yaitu mahasiswa yang aktif atau pasif dan mahasiswa yang mempunyai kemampuan kurang dan kurang sekali. Merumuskan permasalahan dalam pembelajaran, kemudian merumuskan pola kerja siswa dalam pembelajaran dengan penerapan media dinding dalam tenis meja. Menyiapkan rencana pembelajaran, dan lembar observasi mahasiswa.

(b)Sebagai produk perencanaan penelitian, peneliti /dosen telah menyiapkan Rencana Proses Pembelajaran (RPP) dengan menerapkan media dinding Pembelajaran pada siklus 1 disajikan dalam 2 kali pertemuan (sub tindakan).

2) Pelaksanaan Tindakan

(1)Tindakan pembelajaran siklus pertama, pertemuan pertama dilaksanakan pada hari Senin, tanggal 13 Juni 2018, dan pertemuan kedua pada tanggal 20 Agustus 2018 masing-masing disajikan selama 2 jam pelajaran (2x50 menit). Penerapan media dinding disajikan dalam bentuk kelompokkelompok latihan, tiap kelompok terdiri 6 orang.

Pembelajaran menggunakan media dinding Instruksional servis forehand dan backhand: a. Secara klasikal/ bersama-sama mahasiswa mengamati Video instruksional servis forehand dan backhand melalui media dinding yang di tayangkan melalui Infokus.

b. Mahasiswa mengamati dengan cermat, dan mencatat hal-hal penting tiap gerakan dari awalan sampai akhir secara bersamasama.

c. Tiap kelompok secara bertahap berlatih melakukan Teknik pukulan melalui media dinding secara berulang -ulang dan focus dalam melakukan servis tersebut Selama pembelajaran.

3). Hasil Observasi siklus 1

a)Selama proses pembelajaran siklus pertama yang disajikan dalam 2 kali pertemuan peneliti mencatat beberapa hal, diantaranya mahasiswa sangat terpacu untuk melakukan latihan pukulan servis forehand dan backhand melalu dinding.

b)Observasi menggunakan lembar observasi Dosen dan mahasiswa selama pembelajaran diambil 6 mahasiswa secara acak. Mahasiswa yang menjadi sampel merupakan refresentasi dari seluruh mahasiswa yang mewakili dan menunjukkan kondisi pembelajaran dalam kelas tersebut. hanya 35\% dari pembelajaran 90 menit, dan siswa sempat bebas diluar aktivitas pembelajaran terekam selama $15 \%$, dan selebihnya waktu terpakai untuk pengelolaan kelas, waktu menunggu giliran 
bergerak, dan informasi dari dosen pada mahasiswa.

2.Penguasaan dalam pembelajaran bagi mahasiswa dan dosen pada siklus pertama jika dibandingkan dengan data pra-siklus, belum menunjukkan peningkatan yang berarti. Peningkatan baru terjadi pada tingkat keberhasilan di lihat dari lembar observasi

Walaupun peningkatan pembelajaran secara utuh belum terlihat peningkatan yang berarti akan tetapi kemajuan mahasiswa. Peningkatan tersebut diperlihat berdasarkan hasil observasi mahasiswa dan dosen tabel di atas, bahwa :

a.Aspek pendahuluan yang diamati dari mahasiswa terdiri dari 6 penilaian.mengikuti proses pembelajaran Pra siklus Ya (2) dan Tidak (4). Sedangkan penilaian setelah Siklus pertama Ya (3) dan Tidak (3) peningkatan belum cukup signifikan.

b.Aspek inti yang diamati dari mahasiswa terdiri dari 8 penilaian, mengikuti proses pembelajaran Pra siklus Ya (2) dan Tidak (6). Sedangkan penilaian setelah Siklus pertama Ya (4) dan Tidak (2) peningkatan belum cukup signifikan.

c. Aspek Penutup yang diamati dari mahasiswa ada 6 penilaian. mengikuti proses pembelajaran Pra siklus Ya (2) dan Tidak (4). Sedangkan penilaian setelah Siklus pertama Ya (4) dan Tidak (2) peningkatan belum cukup signifikan.

d. Aspek pendahuluan yang diamati dari dosen terdiri dari 6 penilaian.mengikuti proses pembelajaran Pra siklus Ya (3) dan Tidak (3). Sedangkan penilaian setelah Siklus pertama Ya (5) dan Tidak (1) peningkatan belum cukup signifikan.

e. Aspek inti yang diamati dari dosen terdiri dari 8 penilaian, mengikuti proses pembelajaran Pra siklus Ya (3) dan Tidak (5). Sedangkan penilaian setelah Siklus pertama Ya (5) dan Tidak (3) peningkatan belum cukup signifikan.

f. Aspek Penutup yang diamati dari dosen ada 6 penilaian. mengikuti proses pembelajaran Pra siklus Ya (2) dan Tidak (4). Sedangkan penilaian setelah Siklus pertama Ya (3) dan Tidak (3) peningkatan belum cukup signifikan.

3. Temuan Permasalahan yang muncul pada siklus pertama:

- Mahasiswa dan dosen belum baik dalam proses pembelajaran sehingga hasil peningkatan belum signifikan.

Perencanaan Siklus ke Dua

- Temuan-temuan pada siklus kesatu merupakan acuan peneliti untuk merencanakan langkah-langkah penelitian berikutnya. Langkah pertama mengindentifikasi data-data hasil tes keterampilan mahasiswa, hasil observasi pada siklus kesatuBerikutnya temuantemuan permasalahan pada siklus kedua menjadi perhatian khusus untuk dipecahkan pada tindakan pembelajaran berikutnya.

- Perencanaan penelitian pada siklus kedua, peneliti telah menyiapkan Rencana Proses Pembelajaran dengan menerapkan media audio visual video instruksional, disajikan dalam 2 kali pertemuan (sub-tindakan).

- Jumlah anggota tiap kelompok berjumlah 6 orang (sama dengan pembelajaran siklus 1).

- Jumlah kelompok pada siklus ini sebanyak 5 kelompok.

2) Pelaksanaan Tindakan

Pada siklus kedua pembelajaran dilaksanakan 1 kali pertemuan yakni tanggal 19 dan 26 September 2018, tindakan pembelajaran ini dilaksanakan selama 2 jam pelajaran ( $2 \times 50$ menit). Penerapan media dinding disajikan dalam bentuk kelompokkelompok latihan dilakukan dengan langkahlangkah pembelajaran sebagai berikut:

3). Hasil Observasi siklus 2

a) Selama proses pembelajaran siklus kedua yang disajikan dalam 2 kali pertemuan peneliti mencatat beberapa hal, diantaranya mahasiswa sangat terpacu untuk melakukan latihan pukulan servis forehand dan backhand melalu dinding. 
b) Observasi menggunakan lembar observasi Dosen dan mahasiswa selama pembelajaran diambil 6 mahasiswa secara acak. Mahasiswa yang menjadi sampel merupakan refresentasi dari seluruh mahasiswa yang mewakili dan menunjukkan kondisi pembelajaran dalam kelas tersebut. Pengamatan aktivitas mahasiswa dan dosen terekam selama 90 menit pada pertemuan pertama dengan data pada tabel berikut:

(1) Secara klasikal/ bersama-sama mahasiswa mengamati Video instruksional servis forehand dan backhand melalui media dinding yang di tayangkan melalui Infokus.

(2) Mahasiswa mengamati dengan cermat, dan mencatat hal-hal penting tiap gerakan dari awalan sampai akhir secara bersama-sama.

(3) Tiap kelompok secara bertahap berlatih melakukan Teknik pukulan melalui media dinding secara berulang -ulang dan focus dalam melakukan servis tersebut Selama pembelajaran.

Refleksi siklus kedua.

Refleksi perbaikan merupakan analisis hasil data-data penelitian yang terkumpul dan proses pembelajaran melibatkan teman sejawat anggota penelitian dan 3 orang wakil mahasiswa, hasil diskusi diperoleh temuan sebagai berikut:

1) Masalah yang terjadi pada diri mahasiswa, antara lain: hanya sebagian kecil mahasiswa masih menunjukkan sikap kurang sungguh-sungguh, mahasiswa masih kurang giat berlatih, masih ada mahasiswa yang kurang peduli terhadap kegiatan pembelajaran yang disajikan dengan media dinding. Sesuai tabel di atas bahwa waktu efektif mahasiswa berlatih hanya 35\% dari pembelajaran 90 menit, dan siswa sempat bebas diluar aktivitas pembelajaran terekam selama $15 \%$, dan selebihnya waktu terpakai untuk pengelolaan kelas, waktu menunggu giliran bergerak, dan informasi dari dosen pada mahasiswa.
2) Penguasaan dalam pembelajaran bagi mahasiswa dan dosen pada siklus kedua jika dibandingkan dengan data prasiklus, belum menunjukkan peningkatan yang berarti. Peningkatan baru terjadi pada tingkat keberhasilan di lihat dari lembar observasi

Walaupun peningkatan pembelajaran secara utuh belum terlihat peningkatan yang berarti akan tetapi kemajuan mahasiswa. Peningkatan tersebut diperlihat berdasarkan hasil observasi mahasiswa tabel di atas, bahwa :

Walaupun peningkatan pembelajaran secara utuh belum terlihat peningkatan yang berarti akan tetapi kemajuan mahasiswa. Peningkatan tersebut diperlihat berdasarkan hasil observasi mahasiswa dan dosen tabel di atas, bahwa :

a. Aspek pendahuluan yang diamati dari mahasiswa terdiri dari 6 penilaian.mengikuti proses pembelajaran Pra siklus Ya (3) dan Tidak (3). Sedangkan penilaian setelah Siklus pertama Ya (5) dan Tidak (1) peningkatan sudah cukup signifikan.

b. Aspek inti yang diamati dari mahasiswa terdiri dari 8 penilaian, mengikuti proses pembelajaran Pra siklus $\mathrm{Ya}$ (4) dan Tidak (4). Sedangkan penilaian setelah Siklus pertama Ya (7) dan Tidak (1) peningkatan sudah cukup signifikan.

c. Aspek Penutup yang diamati dari mahasiswa ada 6 penilaian. mengikuti proses pembelajaran Pra siklus Ya (3) dan Tidak (3). Sedangkan penilaian setelah Siklus pertama $\mathrm{Ya}$ (5) dan Tidak (1) peningkatan sudah cukup signifikan.

d. Aspek pendahuluan yang diamati dari dosen terdiri dari 6 penilaian.mengikuti proses pembelajaran Pra siklus Ya (4) dan Tidak (2). Sedangkan penilaian setelah Siklus pertama Ya (5) dan Tidak (1) peningkatan sudah cukup signifikan.

e. Aspek inti yang diamati dari dosen terdiri dari 8 penilaian, mengikuti proses pembelajaran Pra siklus Ya (5) dan Tidak (3). 
Sedangkan penilaian setelah Siklus pertama Ya (7) dan Tidak (1) peningkatan sudah cukup signifikan.

f. Aspek Penutup yang diamati dari dosen ada 6 penilaian. mengikuti proses pembelajaran Pra siklus Ya (5) dan Tidak (1). Sedangkan penilaian setelah Siklus pertama Ya (6) dan Tidak (0) peningkatan sudah cukup signifikan.

3)Temuan yang muncul pada siklus Kedua:

a) Mahasiswa dan dosen sudah baik dalam proses pembelajaran sehingga peningkatan naik dengan signifikan.

Adapun hasil pengamatan terhadap mahasiswa dalam proses belajar mengajar pada servis forehand dan backhand melalui media dinding permainan tenis meja pada siklus I adalah sebesar 55\% dari keseluruhan pengamatan terhadap proses belajar mengajar. Pada siklus II meningkat menjadi $85 \%$. Sedangkan hasil pengamatan terhadap dosen pada siklus I sebesar $65 \%$ dan meningkat pada siklus II menjadi $90 \%$. Sehingga dapat disimpulkan bahwa adanya peningkatan yang sangat berarti dalam penerapan pembelajaran servis forehand dan backhand melalui media dinding pada mahasiswa penjas.

\section{PENUTUP}

\section{Simpulan}

Berdasarkan hasil penelitian yang telah dilakukan di mata kuliah pilihan pelajaran tenis meja, peningkatan proses belajar mengajar tenis meja pada servis forehand dan becakhand melalui media dinding. Penelitian ini dilakukan pada jam belajar penjas. Metode penelitian yang digunakan adalah penelitian tindakakn kelas (PTK), penelitian inin secara objektif atau apa adanya dengan subyek penelitian mahasiswa penjas berjumlah 30 orang. Penelitian ini dilakukan dalam 2 siklus, setiap siklus terdiri dari empat tahap yaitu : (1) pendahuluan, (2) ini, (3) penutup. Jenis data yang dikumpulkan adalah data kualitatif berupa hasil observasi aktifivitas dosen dan mahasiswa pada saat proses belajar - mengajar berlangsung. Berdasarkan hasil pengamatan proses belajar mengajar pada servis forehand dan backhand melalui dinding pada tenis meja. Pada pra siklus, siklus I dan siklus II, ada peningkatan terhadap proses belajar mengajar pada pembelajaran servis terhadap mahasiswa, yaitu pada siklus I nilai pengamatan proses belajar mengajar terhadap mahasiswa hanya terlaksana 11 poin atau jika dipresentasekan mencapai $55 \%$ dari keseluruhan penilaian dalam proses belajar dan mengajar, lalu pada siklus II nilai pengamatan proses belajar mengajar terhadap mahasiswa meningkat menjadi 17 poin atau jika dipresentasekan meningkat menjadi $85 \%$. Sedangkan proses belajar mengajar servis forehand dan backhand dosen juga mengalami peningkatan yaitu pada siklus I nilai pengamatan proses belajar mengajar terhadap dosen hanya terlaksana 13 poin atau jika dipresentasekan mencapai $65 \%$ dari keseluruhan penilaian dalam proses belajar mengajar, lalu pada siklus II nilai pengamatan proses belajar mengajar terhadap dosen meningkat menjadi 18 poin atau jika dipresentasekan menjadi 90\%. Dengan demikian dilihat dari pra siklus, siklus I dan siklus II diatas maka dapat dikatakan bahwa dengan penerapan pembelajaran servis forehand dan backhand melalui media dinding dapat meningkatkan hasil proses belajar mengajar mahasiswa pada mata kuliah pilihan tenis meja di kampus penjas unib.

\section{Saran}

Berdasarkan temuan-temuan hasil penelitian yang telah diungkapkan di atas maka peneliti menyarankan pada praktisipraktisi guru/dosen Pendidikan Jasmani dan peneliti lainnya hal-hal sebagai berikut;

1) Bagi Guru/ dosen Penjas yang mengalami kesulitan dalam membelajarkan siswa dalam meningkatkan pukulan servis dalam tenis meja dengan melalui media dinding serta 
dapat memodifikasi media yang lain agar dapat mempermudah mahasiswa dalam berlatih servis pada tenis meja sebagai upaya meningkatkan proses pembelajaran yang aktif dan inovatif dalam meningkatkan keterampilan .

2) Kepada para siswa hendaknya terus aktif dalam proses belajar mengajar terutama dalam penguasaan servis forehand dan backhand dalam tenis meja.

3) Bagi peneliti lainnya agar dapat menindak lanjuti penelitian penerapan media dinding dalm servis forehand dan backhand dalam tenis meja agar dalam pelaksanaanya berhasil dan lebih baik.

\section{Daftar pustaka}

Achmad Damiri dan Nurlan Kusmaedi. 1992. Olahraga Pilihan Tenis meja. Jakarta: Depdikbud.

Alex Kertamanah. 2003.Teknik dan Taktik Dasar Permainan Tenis Meja. Jakarta: Raja Grafindo Persada

Damiri Ahmad Kusnaddi Nurlan. 1992. Olahraga Pilihan Tenis Meja. Depdikbud. Dirjen Dikti. P2LPTK. Jakarta.

Leach Jhonny. 1982. Bimbingan Bermain Tenis Meja. Alih bahasa Is Daulay. Muhara. Jakarta.

Martens Reiner. 1996. Table Tennis Step To Succes diterjemahkan oleh Nasution D. Eri. PT. Raja Grafindo Persada. Jakarta.

Nurhasanah, 2008, Penilaian Pembelajaran Penjas, Jakarta: Universitas Terbuka.

Peter Simson,2008 Teknik Bermain Pimpong Bandung : CV Pioneer Jaya

Samsudin,2008, Pemanfaatan Lingkungan dalam Pembelajaran Penjas, Jakarta: Universitas Terbuka.

Sutarmin. 2007. Terampil Berolahraga Tenis Meja. Surakarta: Era Intermedia.
Tatang Muhtar dan Wahyu Sulistyo, 2009, Tenis Meja, Jakarta: Universitas Terbuka.

Toto Subroto, 2008, Strategi Pembelajaran Penjas, Jakarta: Universitas Terbuka

Sutarmin,2007,Terampil Berolahraga Tenis Meja, Surakarta :Era Intermedia. 